\title{
Evaluating effects of conventional practice and straw mulch applications on moisture conservation in semi arid Ethiopia.
}

\author{
Fikre A*, Ayana M, Alaro A, Mamo G \\ Water Resource Research Center, Arbaminch Institute of Technology, Arbaminch, Ethiopia
}

\begin{abstract}
The dry land areas of Ethiopia account for more than $66.6 \%$ of total land area, and are substantial crop producing areas fall within the semi-arid parts. As a result, crops experience moisture stress at any time during their growth stage. The first action to improve agricultural production in the dry land areas is to apply moisture conservation techniques and then use the limited water efficiently for enhancing water productivity. A study was conducted at Holte kebelle of Dirashae district from April 1, 2016-July 31, 2016 to evaluate effects of conventional practice and straw mulch applications on soil moisture conservation and yield of sorghum under rainfed agriculture with six levels of sorghum straw mulch. The experiment was designed as a single factor experiment in randomized complete block design and replicated four times. Soil moisture has been taken for six times of $30 \mathrm{~cm}$ interval up to sorghum root depth $(90 \mathrm{~cm})$ in 3 weeks interval and analyzed volumetric moisture content. Physical and chemical properties, Field Capacity and Permanent Wilting Point in respective depths were analyzed. The analysis of variance indicated that there was highly significant difference $(p \leq 0.05)$ for soil moisture contents determined at $0-30 \mathrm{~cm}, 30-60 \mathrm{~cm}$ and $60-90 \mathrm{~cm}$ at different sorghum growth stages and straw applied. 2.2 and 3.0 ton/ha straw mulch prolonged the days to harvesting due to more moisture conservation in the soil profile and significant in growth and yield parameters. The maximum volumetric soil moisture content was recorded in 2.2 and 3.0 ton/ha straw mulch, which were between the Field Capacity and Permanent Wilting Point at different growth stages of sorghum however, grain yield was higher in $2.2 \mathrm{t} / \mathrm{ha}$. Based on the experiment therefore, application of $2.2 \mathrm{ton} / \mathrm{ha}$ of sorghum straw mulch was found more effective in conserving soil moisture for maximum yield under rain-fed agricultural system better than other treatments.
\end{abstract}

Keywords: Rain-fed agriculture, moisture stress, moisture conservation, straw mulching.

\section{Introduction}

The Ethiopian dry lands in general which account for $67 \%$ of the country's total land area and the agriculture sector in particular, have been identified as vulnerable to climate variability and land degradation [1-4]. Water is the main requirement for healthy plant growth for instance, improving soil and water conservation is the first action to improve the water supply for agriculture [5], utilizing the rain water effectively and efficiently that falls onto the catchment. Most arid and semi-arid regions; however, suffer from insufficient and unreliable rainfall. In these areas, a high rate of evaporation in the growing season is also common $[5,6]$.

Low soil moisture due to unevenly distributed rainfall, severe soil erosion and runoff loss of water and the resultant low soil fertility are the prominent causes for the low agricultural productivity in the semi-arid areas of Ethiopia. In addition to accelerated soil erosion and the alarming rate of land degradation, the loss of water as runoff coupled with periodic drought during the cropping season on degraded lands supporting rain fed crop production was also equally important $[7,8]$. The timely and adequate supply of water to crops during critical parts of the growing period is the main determinant of crop production. In much of dry lands, rainfall is not always adequate to enable crops to reach more than a small fraction of their potential yield, since rainfall is variable both from year to year and within the growing season $[9,10]$.

In rain-fed agriculture, users are showing high interest in the large range of low-cost agricultural water management technologies in semi-arid developing countries to avert the scarcity of water. This is in response to the observation that unreliable water supply is one of the biggest threats to the food security of poor small farmers. The vast majority of the rural poor rely on rainfed land for their survival, making them vulnerable to the highly variable and unpredictable rainfall. According to IMWI [11] Periodic drought and famine are the result, especially in many Sub-Saharan African countries.

Mulching have benefits attributed to physical effects that minimize raindrop impact and improve rainfall acceptance through enhancement of soil structure and reduce erosion; biological effects that increase the activity and species diversity of soil flora and fauna, notably earthworms increased biomass carbon, and improved crop growth [12] and chemical effects that alter nutrient status and influence crop growth. The major limitations lie in the large quantities of residues required (usually 4 ton/ha/yr) [13]. The higher mulch rate provides higher soil moisture, yield, and improve soil physical, chemical and biological properties [14,15]. 
Cereals are the major food crops grown in Ethiopia; as a result sorghum is one of the major traditional crops grown mainly in the dry semi-arid areas of Ethiopia. It is a staple major food crop for millions of people who live in the dry land areas of the country. Sorghum is indigenous to Ethiopia and thus has tremendous range of genetic variability [16]. It is widely grown in Derashe area of Ethiopia and used as stable traditional food and drink called Cheka. Derashe is well known by indigenous knowledge of straw application on the ridge (mona) of row planting basin as practice to conserve moisture and reduce cumulative runoff. The rained moisture on that field stay as depression storage and through time seep in to the soil profile then plants use this stored moisture when they get stressed on the growth season of sorghum.

Application of mulch has high potential to conserve soil moisture that halt the moisture from soil particles, facilitate infiltration and hinder runoff. Mulch also contributes to water conservation through addition of organic matter that improves soil aggregation and porosity and as a physical layer covering soil to reduce splashing of soil when rain dropping, surface runoff and evaporation. Therefore, mulching is one of the promising technologies that is an integral component of conservation farming and is increasingly seen in the light of integrated soil management for sustainable agriculture [17-19].

The problem of water shortage for the crops in the Derashe area is caused by limited and uneven distribution of rainfall for the growth of crop throughout the cropping season. Moreover, much of the rain occurs with high intensity resulting excessive runoff and severe soil erosion. Due to these problems, agricultural production is highly reduced especially through depletion of soil moisture. Conventional practice is application of straw on the prepared ridges is widely practiced in Derashe area as indigenous knowledge of the area. To improve land production in moisture stress area of Ethiopia particularly Holte area, a quantitative understanding of soil moisture conservation through application of straw mulching in between rows of the plants in the growing season of sorghum is essential. Since there is a need to find agricultural water management practices that would reduce water losses and favor water efficient utilization to improve water productivity.

\section{Objectives}

1. To evaluate the effects of conventional practice and mulching practices on moisture conservation and crop productivity.

2. To determine mulching rate for optimum soil moisture conservation.

\section{Materials and Methods}

\section{Description of the study area}

Ethiopia is a country with great ecological and agro-ecological diversity ranging from lowland savannahs to alpine plateau and a very old civilization. According to socio-economic development study of derashe woreda [20], derashe bordered on the south with Konso special woreda, on the west with the Weito River which separates it from the Debub Omo Zone, on the north with the Gamo Gofa Zone, on the northeast with Lake Chamo, and on the east with Amaro special woreda.
Topographically it lies between 501-2500 m a.s.1., having mean annual temperature and rainfall ranges between $15.1-27.5^{\circ} \mathrm{C}$. and 601-1600 mm respectively. Agriculture is the major source of income and livelihood for the community; however, due to traditional farming practice, erratic rainfall, low agricultural input utilization and low skilled manpower seem to have hampered the development of the agricultural sector. The main crops grown in the area are sorghum, maize, barley, wheat, potato, coffee, cotton, etc. [20].

Particularly, the total rainfall $(332.7 \mathrm{~mm})$ recorded over the period of the cropping season in study area is below the normal range for the area and could be seen as minimum rain fall for crop growth. Out of $217.0 \mathrm{~mm}$ monthly rainfall of April 127.0 which is $59 \%$ of the rainfall was recorded only on four days, which showed very low distribution of rain fall in the entire cropping season.

The rainfall data recorded for the cropping season revealed that crop production in the study area is heavily constrained by severe soil moisture stress. Besides to shortage of water, uneven distribution of rainfall in intensity and frequency of rainfall occurrence among the months and within days of a month over the cropping season. The rainfall rained in the months of June and July were very limited, while the crop were in vegetative growth stage period appeared to be a critical limitation in yield and a complete failure in other crops. Thus, erratic and insufficient rainfall and the resultant limited availability of soil moisture coupled with the exceptional risks of prolonged dry spells are the major constraints of crop production at Holte area (Figure 1).

\section{Soil sampling}

Using an auger, disturbed composite surface soil samples (0-30 cm depth) was collected from the cultivated land of the experimental field just before sowing the crop to 42 days. In addition, soil samples were collected up to root zone depth $(90 \mathrm{~cm})$ at an interval of $30 \mathrm{~cm}$ with the help of hand auger from

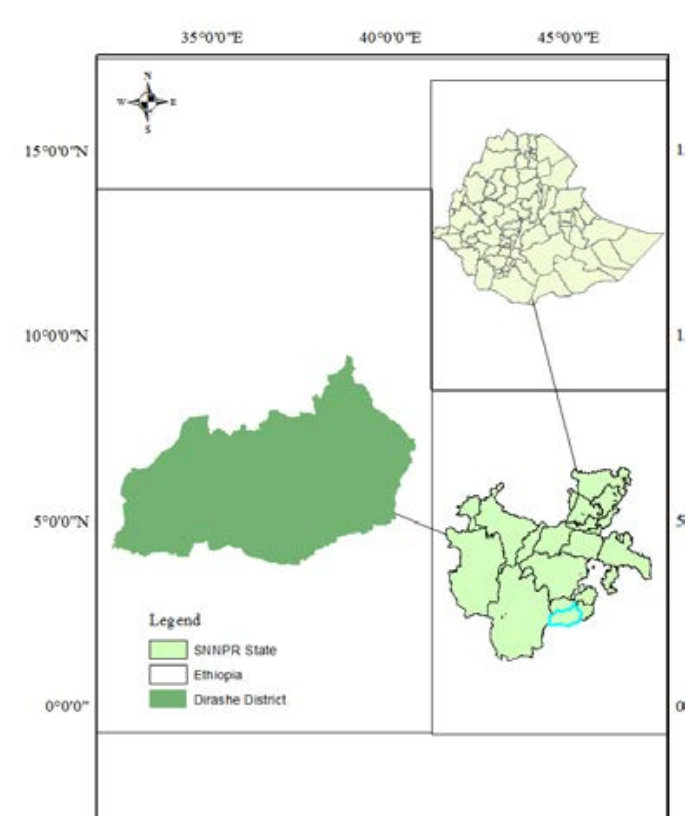

Figure 1: Microbial colonies as observed on petri-plates 
each plot every 21 days from booting to harvesting for moisture determination. Moreover, a soil profile was opened and sampled horizon wise and analyzed for its selected soil physicochemical properties. In addition, undisturbed soil samples were collected in cylinders using core samples from each horizon of the profile for the determinations of bulk density, particle density and moisture content at different tensions.

The disturbed surface soil and profile soil samples were airdried and grind to pass through a $2 \mathrm{~mm}$ sieve in preparation for laboratory analysis. Roots and coarse materials were removed by sieving. The fraction less than $2 \mathrm{~mm}$ in diameter was used for laboratory analysis of selected physical and chemical properties of the soil samples.

\section{Treatments and experimental design}

The treatments considered in this experiment were no mulch and no indigenous conservation practice-control (T0), 3.7 ton/ha straw on the ridge /indigenous conservation practice/conventional practice (T1), 0.75 ton/ha mulch with conventional conservation practice (T2), 1.5 ton/ha mulch with conventional conservation practice (T3), 2.2 ton/ha mulch with conventional conservation practice (T4), and 3.0 ton/ha mulch with conventional conservation practice (T5). Conventional (Indigenous conservation) practice which is the commonly practice by farmers in the study area was used as a common for all treatments except the control. The technique, after a minimum tillage ridge were constructed with tilled soil (mona), which uses as basins/mini-catchment for the crops to store moisture (Poteya) with a size of $3 * 4.5=13.5 \mathrm{~m}^{2}$, then straw was applied on the ridge (Targa). Row formed and seeds (gubeye variety) sowed, then the required mulches were applied immediately after sowing as per the design.

The experimental design used was randomized complete block design (RCBD) with four replications. Each treatment was applied on a plot size of $3 \mathrm{~m} \times 4.5 \mathrm{~m}\left(13.5 \mathrm{~m}^{2}\right)$ separated by a distance of $1.5 \mathrm{~m}$ between blocks and $1 \mathrm{~m}$ within plots. With a spacing of $20 \mathrm{~cm}$ between plants and $75 \mathrm{~cm}$ between rows, a plot constitutes of six rows of sorghum plants. Nitrogen and phosphorous fertilizers were applied to each plot at the rate of $100 \mathrm{Kg} / \mathrm{ha}$ of urea and $100 \mathrm{~kg} / \mathrm{ha}$ of Diammonium phosphate (DAP).

\section{Data collection and analysis}

Data recorded during the experiment were rainfall, temperature, plant height, panicle length, grain yield and 100 seed weight.
Plant and yield components were recorded from the central three rows of the net plot area. Five random plants per row in the plot excluding the border rows and border plants in the central rows were taken. Weight of seeds and seed yield per plot have been determined from air-dry weight of seeds at $12.5 \%$ moisture content of the net plot area. Analysis of variance was used for SAS 9.14 to carry out the experiment at 5\% levels of significance.

\section{Results and Discussion}

\section{Soil physical and chemical properties}

The cumulative particle size distribution of disturbed soil up to $90 \mathrm{~cm}$ depth indicated that the soil was clayey in the experimental field. The $\mathrm{pH}$ is alkaline soil reaction, it is in a suitable range for sorghum production and organic matter is low as compared to nutrients standard rating given [21]. The experimental field had average value of $0.11 \%$ total $\mathrm{N}, 22.26$ ( $\mathrm{mg} \mathrm{P}_{2} \mathrm{O}_{5} / \mathrm{kg}$ soil) available $\mathrm{P}$ and $112.65 \mathrm{ppm}$ of exchangeable $\mathrm{K}$. According to Landon, total nitrogen and available $\mathrm{P}$ were low [21] and exchangeable $\mathrm{K}$ was high [22,23].

The soil has bulk density increased with depth, due to compaction. Besides, the water content at field capacity, permanent wilting point and total available moisture, the soil were increasing with depth. This was due to less evaporation effect and less availability of moisture to plants in the deeper layers. On the conterary total porosity for the horizons were decreasing which was negatively correlated with depth and too low to drain the water (Tables 1 and 2).

\section{Soil moisture content at sowing}

A perusal of the data on the soil moisture content at sowing time and analysis of variance revealed that there was no significant differences $(\mathrm{P}>0.05)$ due to the application of mulching as compared to the water retained by the flat non mulched bed (T0) at 0-30 cm soil depths. Since the field was uniform and there was no difference in soil type across the plots, the moisture content of the plot in the given planting date remained same for the effects of mulching rate applied.

\section{Soil moisture content at 21 days of sowing}

The soil moisture content at 21 days of planting was significantly influenced by straw mulching applied. T4 and T5 showed highly significant over T0. This is probably due to the effect of evaporation through the mulched straw and effectiveness in retaining water. The findings of this study indicated the

Table 1. Soil texture, $p H$, electrical conductivity, and organic matter content of the experimental site.

\begin{tabular}{|c|c|c|c|c|c|c|c|}
\hline Sampling depth(cm) & Soil PH & EC(dS/m) & Soil organic matter (\%) & Sand (\%) & Silt (\%) & Clay (\%) & Class \\
\hline $0-30$ & 8.13 & 0.17 & 0.86 & 22.21 & 24.45 & 53.34 & Clay \\
\hline $30-60$ & 8.26 & 0.15 & 0.79 & 26.26 & 17.88 & 55.86 & Clay \\
\hline $60-90$ & 8.37 & 0.16 & 0.78 & 19.88 & 22.25 & 57.86 & Clay \\
\hline Average & 8.25 & 0.16 & 0.81 & 22.78 & 21.53 & 55.69 & Clay \\
\hline
\end{tabular}

Table 2. Field capacity, permanent wilting point and total available moisture of the experimental field.

\begin{tabular}{|c|c|c|c|c|c|}
\hline Sampling depth (cm) & Bulk density $\left(\mathrm{g} / \mathrm{cm}^{3}\right)$ & $\mathrm{FC}(\%)$ & PWP (\%) & AWC $(\mathrm{mm} / \mathrm{m})$ & $P(\%)$ \\
\hline $0-30$ & 1.37 & 39.52 & 25.93 & 55.85 & 48.3 \\
\hline $30-60$ & 1.45 & 44.1 & 31.6 & 54.38 & 45.28 \\
\hline $60-90$ & 1.49 & 45.6 & 32.85 & 57 & 43.77 \\
\hline
\end{tabular}


effectiveness of straw mulching as in situ water conservation, which enabled each drop of water to be held on the field and absorbed by the soil (Table 3).

\section{Soil moisture content at 42, 63, 84 and 105 days of sowing}

From 42 days of sowing to full maturity sampling depth was extended up to $90 \mathrm{~cm}$ of the soil profile, because the crop root expected growing vertically as well laterally and consumes moisture from deeper soil profile. The analysis of variance revealed that soil moisture content at T4 and T5 showed highly significant over the other treatments, and these are the only treatments that were significant in depth of $60-90 \mathrm{~cm}$. The conventional method provides better moisture conservation ability than the lower rate of mulch application in various depths of sampling period (Figure 2).

\section{Soil moisture content with field capacity and permanent wilting point at various depths}

The average soil moisture content showed an increasing trend with soil depth almost in all treatments. The volumetric soil moisture content found at 0,21, 42 and 63 days of sowing was between FC and PWP except T0 at various sampling depths. This was due to the rainfall rained during these periods had relatively better amount and distribution.

The volumetric soil moisture content at 84 and 105 days of sowing, found at soil depth of 0-30 cm was between FC and PWP except T0; and the highest moisture level was on T4 but the lowest moisture content was due to T0. However, the volumetric soil moisture contents determined at depths of 3060 was below PWP except T2 and T4, and the volumetric soil moisture contents determined at depths of $60-90 \mathrm{~cm}$ was below
PWP for all treatments. This might be due to the larger value of the FC and PWP at these depths. Moreover, available water started to decrease at this time because rainfall was almost ceased before a month of this sampling time. However, moisture at this stage is critical to sorghum crop due to seed filling high moisture requirement by the crop is expected, but the available moisture observed was below the demand and causes reduction of yield.

\section{Plant height}

The effect of the applying different levels of mulch on sorghum growth pattern was initially small, followed by large increase at 42 and 63 days after sowing. The analysis of variance revealed that plant height was significantly influenced by T5 as compared to T0. Not only on non- mulched plots but also T5 showed a difference over $\mathrm{T} 1$ and $\mathrm{T} 3$; this might due to having of high quantity of straw mulch to prevent evaporation from the surface. The maximum plant height was recorded on and the minimum was observed $1.47 \mathrm{~m}$ at $\mathrm{T} 0$. This indicates there was positive relation between mulch amount and plant height and moisture content.

\section{Panicle length}

The analysis of variance indicated that panicle length was affected significantly due to the applications of straw mulch. This could be due to their better accumulation of moisture for full growth and maturity of panicles (Table 4).

\section{Hundred seeds weight}

A perusal of the analysis of variance revealed that there was no difference in hundred seeds weight among treatments and

Table 3. Volumetric soil moisture content (\%) at various soil depths and sampling periods.

\begin{tabular}{|c|c|c|c|c|c|c|c|c|c|}
\hline $\operatorname{Depth}(\mathbf{c m})$ & & & Treatments & & & & $\operatorname{LSD}(0.05)$ & CV $(\%)$ & $\mathrm{SE}( \pm)$ \\
\hline & T0 & $\mathrm{T} 1$ & $\mathrm{~T} 2$ & $\mathrm{~T} 3$ & $\mathrm{~T} 4$ & $\mathrm{~T} 5$ & & & \\
\hline & & \multicolumn{2}{|c|}{ At 21 days of sowing } & & & & & & \\
\hline \multirow[t]{2}{*}{$0-30$} & $40.43^{\mathrm{b}}$ & $47.12^{\mathrm{ab}}$ & $47.69^{\mathrm{ab}}$ & $45.42^{\mathrm{ab}}$ & $45.16^{\mathrm{aa}}$ & $46.90^{\text {aa }}$ & 0.0151 & 5.9841 & 0.70611 \\
\hline & & \multicolumn{2}{|c|}{ At 42 days of sowing } & & & & & & \\
\hline $0-30$ & $41.72^{\mathrm{c}}$ & $49.30^{\mathrm{bb}}$ & $48.43^{\mathrm{bb}}$ & $50.62^{\mathrm{ab}}$ & $54.19^{\text {aa }}$ & $54.17^{\text {aаa }}$ & 0.0001 & 5.46475 & 1.00548 \\
\hline $30-60$ & $37.86^{\mathrm{c}}$ & $49.96^{\mathrm{bb}}$ & $55.61^{\mathrm{ab}}$ & $53.05^{\mathrm{bb}}$ & $64.13^{\text {aa }}$ & $54.06^{\mathrm{ab}}$ & 0.0015 & 13.0619 & 2.04976 \\
\hline \multirow[t]{2}{*}{$60-90$} & $51.11^{\mathrm{b}}$ & $66.46^{\mathrm{aa}}$ & $61.73^{\text {aa }}$ & $63.48^{\text {aa }}$ & $69.98^{\text {aa }}$ & $67.31^{\text {aa }}$ & 0.0158 & 10.7757 & 1.76815 \\
\hline & & \multicolumn{2}{|c|}{ At 63 days of sowing } & & & & & & \\
\hline $0-30$ & $40.43^{\mathrm{c}}$ & $46.90^{\mathrm{bb}}$ & $44.94^{\mathrm{bb}}$ & $47.42^{\mathrm{ab}}$ & $47.69^{\text {aa }}$ & $47.17^{\text {aa }}$ & 0.0101 & 5.91974 & 0.7218 \\
\hline $30-60$ & $42.86^{\mathrm{c}}$ & $50.96^{\mathrm{bb}}$ & $54.66^{\mathrm{ab}}$ & $52.99^{\mathrm{bb}}$ & $72.37^{\text {aa }}$ & $65.52^{\mathrm{ab}}$ & 0.1761 & 27.05394 & 3.2666 \\
\hline \multirow[t]{2}{*}{$60-90$} & $49.81^{\mathrm{b}}$ & $73.56^{\text {aa }}$ & $58.23^{\text {aа }}$ & $58.28^{\text {aa }}$ & $68.48^{\text {aa }}$ & $60.31^{\text {aa }}$ & 0.3444 & 24.87644 & 3.1905 \\
\hline & & \multicolumn{2}{|c|}{ At 84 days of sowing } & & & & & & \\
\hline $0-30$ & $33.03^{\mathrm{b}}$ & $41.074^{\mathrm{ab}}$ & $45.53^{\text {aа }}$ & $41.57^{\mathrm{ab}}$ & $42.58^{\mathrm{aa}}$ & $42.27^{\text {aa }}$ & 0.0078 & 9.70733 & 1.07753 \\
\hline $30-60$ & $38.34^{\mathrm{b}}$ & $51.24^{\text {aa }}$ & $52.14^{\text {aa }}$ & $49.67^{\text {aa }}$ & $50.83^{\text {aа }}$ & $50.26^{\mathrm{aa}}$ & 0.0001 & 4.66173 & 1.08962 \\
\hline \multirow[t]{2}{*}{$60-90$} & $51.06^{\mathrm{b}}$ & $40.75^{\text {aa }}$ & $53.15^{\text {aа }}$ & $52.89^{\text {aа }}$ & $52.49^{\text {aa }}$ & $53.70^{\text {aa }}$ & 0.0001 & 5.374 & 5.31438 \\
\hline & & \multicolumn{2}{|c|}{105 days of sowing } & & & & & & \\
\hline $0-30$ & $31.44^{\mathrm{b}}$ & $39.49^{\text {aa }}$ & $39.45^{\text {aa }}$ & $38.99^{\text {aa }}$ & $39.84^{\text {aa }}$ & $38.38^{\text {aa }}$ & 0.003 & 7.22499 & 3.86062 \\
\hline $30-60$ & $36.56^{\mathrm{b}}$ & $47.56^{\mathrm{ab}}$ & $57.11^{\text {aa }}$ & $47.85^{\mathrm{ab}}$ & $60.13^{\text {aa }}$ & $47.06^{\mathrm{ab}}$ & 0.078 & 21.8967 & 2.52091 \\
\hline $60-90$ & $42.33^{\mathrm{b}}$ & $51.13^{\text {aa }}$ & $50.73^{\text {aa }}$ & $50.79^{\text {aa }}$ & $49.87^{\text {aa }}$ & $49.93^{\text {aа }}$ & 0.001 & 5.42389 & 0.80141 \\
\hline
\end{tabular}

Note: * means with the same letter are not significantly different. 

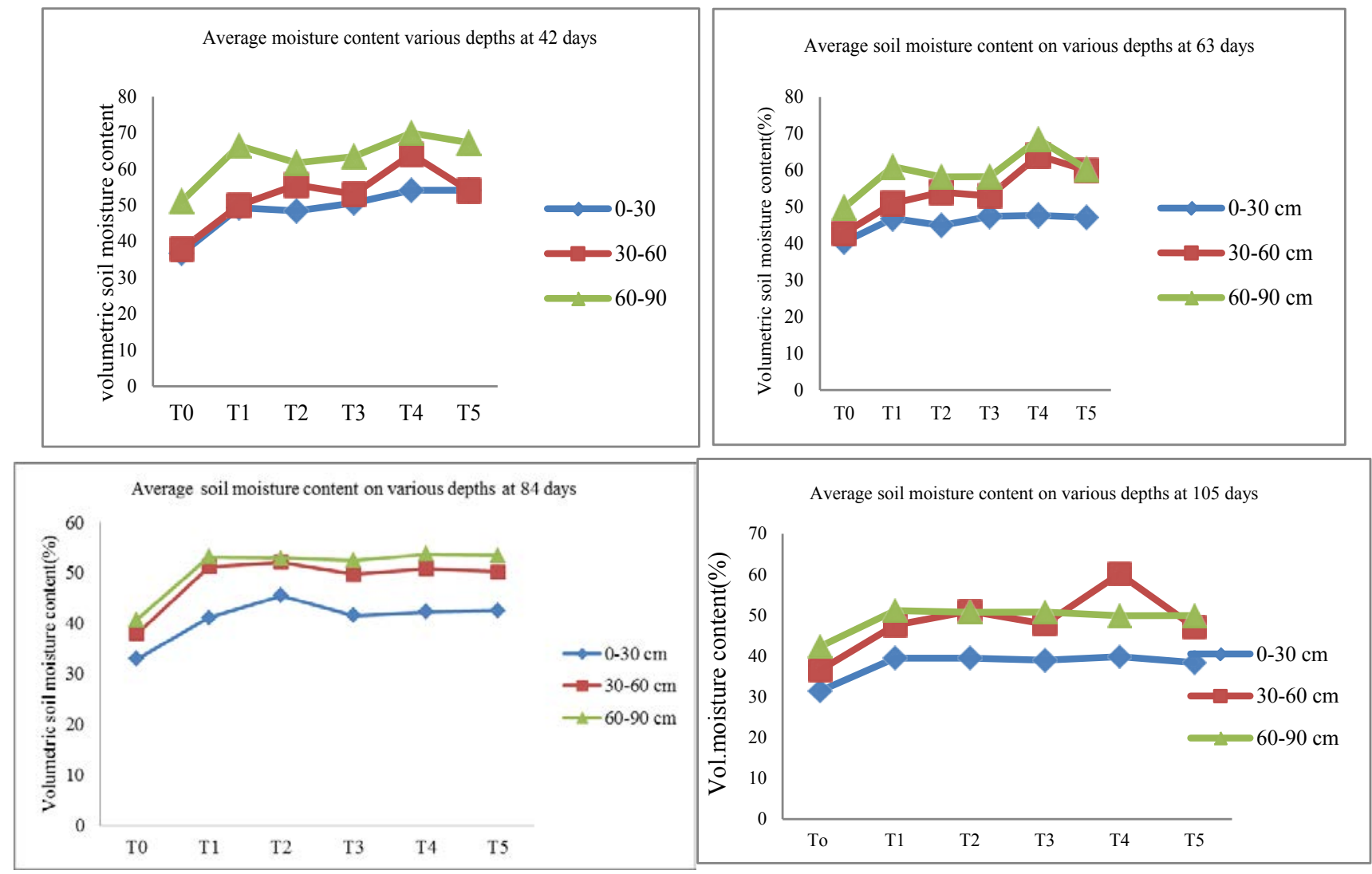

Figure 2. Volumetric average moisture content of treatments during the four sampling periods.

Table 4. Crop phenology, plant heights, yield and yield components of sorghum as affected by treatments.

\begin{tabular}{|c|c|c|c|c|c|c|c|c|c|}
\hline \multirow[t]{2}{*}{ Parameter } & \multicolumn{6}{|c|}{ Treatments } & \multirow[t]{2}{*}{$\operatorname{LSD}(0.05)$} & \multirow[t]{2}{*}{ CV(\%) } & \multirow[t]{2}{*}{$\mathrm{SE}( \pm)$} \\
\hline & TO & T1 & T2 & T3 & T4 & T5 & & & \\
\hline Plant height & $1.28^{\mathrm{bb}}$ & $1.3265^{\mathrm{ab}}$ & $1.3675^{\text {aa }}$ & $1.348^{\mathrm{ab}}$ & $1.3695^{\mathrm{aa}}$ & $1.3885^{\mathrm{aa}}$ & 0.0667 & 3.63061 & 0.01152 \\
\hline Panicle length & $0.275^{\mathrm{bb}}$ & $0.2725^{\mathrm{ab}}$ & $0.273^{\text {aa }}$ & $0.2695^{\mathrm{aa}}$ & $0.263^{\text {aa }}$ & $0.25^{\mathrm{aa}}$ & 0.0232 & 3.7864 & 0.00256 \\
\hline Grain yield & $0.595^{\mathrm{cc}}$ & $0.7024^{\mathrm{bc}}$ & $0.88863^{a b c}$ & $0.63815^{c c}$ & $1.05825^{\mathrm{ab}}$ & $1.02143^{\mathrm{aa}}$ & 0.0221 & 26.1568 & 0.05419 \\
\hline 100 's seed weight & $1.825^{\mathrm{a}}$ & $1.925^{\mathrm{a}}$ & $2.1^{\mathrm{a}}$ & $1.925^{\mathrm{a}}$ & $2.07^{a}$ & $2.0175^{\mathrm{a}}$ & 0.4898 & 10.9458 & 0.04379 \\
\hline
\end{tabular}

Note: * means with the same letter are not significantly different.

the control. In fact it was expected that the seeds which were supplied with adequate moisture have matured well to have heavier seed weight than those exposed to moisture stress but statistically it was not significant.

\section{Grain yield}

ANOVA revealed that grain yield was significantly influenced on T4 and T5 as compared to T0. The lowest sorghum grain yield was obtained on T0, whereas the highest average grain yield was on T4 and T5. The low sorghum yield in the present finding was due to early cessation of rainfall during flowering stage.

\section{Conclusion}

Average soil moisture content determined during all stages was showed an increasing trend with soil depth for almost all treatments. Moreover, the plant penology has direct relation with the rate of applied mulches. The conventional practice retain better moisture and plant phenology than the control; however 2.2 and 3.0 t/ha with conventional are superior than all. Water productivity and yield were increased with the rate of mulches applied.
Application of straw mulch with the conventional practice as part of soil and water conservation practices affect the erosion processes and reduced water and soil loss as runoff, absorbing runoff scour forces, reduce rate of runoff and improved soil water storage in the profile by enhancing infiltration which was important in increasing sorghum yield. Besides, it have the benefits in the accumulation of more moisture in the soil, reduce the loss of moisture through evaporation, prevent early weed growth, promote microbial activities and addition of organic matter in to the soil.

\section{Acknowledgement}

The Authors would like to thank Arba Minch University for providing research budget, laboratory accessibility and transportation facility to accomplish the research. Our sincere gratitude goes also to Holte kebelle Agricultural office members for making everything easy in the research site, especially Mr. Tamiru Takele and farmer Mezigob Fenu who accepts the research idea and provision of experimental land.

\section{References}

1. Asefa K, Giorgis AW, Tarekegn D, et al. Climate Change Environ Risk Assess Remediat 2018 Volume 2 Issue 3 
National Adaptation Programme of Action (NAPA) of Ethiopia. Ministry of Water Resources and National Meteorological Agency. 2007.

2. Niang I, Ruppel OC, Abdrabo MA. Africa. In: Barros VR, Field CB, Dokken DJ, et al. (eds) Climate Change Impacts, Adaptation, and Vulnerability. Part B: Regional Aspects. Contribution of Working Group II to the Fifth Assessment Report of the Intergovernmental Panel on Climate Change. Cambridge, UK, New York, NY: Cambridge University Press. 2014:1199-1265.

3. Nyssen J, Poesen J, Moeyersons J, et al. Human impact on the environment in the Ethiopian and Eritrean highlands: A state of the art. Earth-Science Reviews. 2004;64:273-320.

4. UNEP. Adaptation to Climate-change Induced Water Stress in the Nile Basin: A Vulnerability Assessment Report. Nairobi, Kenya: Division of Early Warning and Assessment (DEWA), United Nations Environment Programme (UNEP). 2013.

5. Rockström J. Water Resources Management in Smallholder Farms in Eastern and Southern Africa: An Overview. Physicsand Chemistry of the Earth. 2000;25:275-283.

6. Anschütz J, Antoinette $\mathrm{K}$, Nederlof $\mathrm{M}$, et al. Water Harvesting and Soil Moisture Retention. Agrodok 13, Wageningen, Netherlands: Agromisa Foundation. 2003.

7. Hawando T. The role of improved soil, water and crop management practices in increasing agricultural production in Ethiopia; Paper presented at the National Workshop on Food Strategies for Ethiopia, Alemaya. 1986:8-13.

8. Gebrekidan H, Uloro Y. Soil and Water Conservation (tied ridges and planting methods) on cultivated lands: The case of Eastern Ethiopia; Soil and Water Management Research Program. 2002.

9. Georgis K, Temesgen M, Goda S. On Farm Evaluation of Soil Moisture Conservation Techniques Using Improved Germoplasm. 2001:13-316.

10. Food and Agriculture organization of United Nations (FAO). A Perspective on Water Control in Southern Africa Support to Regional Investment Initiatives Importance Land and Water Discussion paper. Italy. 2003.

11. International Water Management Institute (IWMI). A Literature Study to Support the Implementation of MicroAgricultural Water Management Technologies in the SADC Region. Colombo, Sri Lanka:IWMI. 2006.
12. Erenstein O. Crop residue mulching in tropical and semitropical countries: An evaluation of residue availability and other technological implications. Soil \& Tillage Research. 2002;67:115-133.

13. Lal R. Sustainable management of soil resources in the humid tropics. United Nations University. 1995.

14. Pervaiz M, Iqbal M, Shahzad K et al. Effect of mulch on soil physical properties and NPK concentrate on in maize (Zea mays L.) shoots under two tillage systems. International Journal of Agriculture and Biology. 2009;11:119-124.

15. Lal R. Mulching effects on runoff, soil erosion, and crop response on Alfisols in Western Nigeria. Journal of Sustainable Agriculture. 1998;11:135-154.

16. Moges Y. Innovations in Dry Land Farming Techniques Consultancy Sub-Report No. 5. Adis Ababa, Ethiopia: Farm Africa/SOS Sahel. 2004.

17. Food and Agriculture organization of United Nations (FAO). Soil Tillage in Africa: Needs and Challenges. FAO soils bulletin 69. Italy. 1993.

18. Erenstein O. Smallholder conservation farming in the tropics and sub-tropics: a guide to the development and dissemination of mulching with crop residues and cover crops. Agriculture, Ecosystems and Environment. 2003;100:17-37.

19. Mueller P, Finney D, Hepperly P. The Field System.. In: Moore, K. (ed.), The Sciences and Art of Adaptive Management: Innovating for Sustainable Agriculture and Natural Resource Management: Soil and water conservation society. 2009:25-59pp.

20. Socio-economic development Study of Derashe Woreda (SESDW). 2013.

21. Landon JR. Booker tropical Soil Manual: A Hand Book of Soil Survey and Agricultural Land Evaluation in the Tropics and Subtropics. New York, USA: Longman Inc. 1991.

22. Marx ES, Hart J, Stevens RG. Soil Test Interpretation Guide. Oregon State University Extension Service. 1999.

23. Erenstein O. Crop residue mulching in tropical and semitropical countries: An evaluation of residue availability and other technological implications. Soil \& Tillage Research. 2002;67:115-133.

\section{*Correspondence to:}

Asrat Berke Fikre

Lecturer and Researcher

Wolkite University

Wabe Gubere Berg

Ethiopia

Tel: $+251910455512 /+251976140278$

Fax: +2510025113320041

E-mail: etye1979@gmail.com 